\title{
The Impact of Research and Development on the Financial Sustainability of Information Technology (IT) Companies Listed on the S\&P 500 Index
}

\author{
Priyanka Dave $^{1}$, Varun Wadhwa ${ }^{1}$, Shrey Aggarwal ${ }^{1} \&$ A. Seetharaman ${ }^{2}$ \\ ${ }^{1}$ Post Graduate Scholar, SP Jain School of Global Management, Singapore \\ ${ }^{2}$ Dean Academic Affairs, SP Jain School of Global Management, Singapore \\ Correspondence: Varun Wadhwa, A/2 - 301, Golders Green, I.C.Colony, Borivali (W), Mumbai 400103, India. \\ Tel: 91-9819-718161. E-mail: varunwadhwa@aol.in
}

\author{
Received: July 14, 2013 Accepted: October 2, 2013 Online Published: October 24, 2013 \\ doi:10.5539/jsd.v6n11p122 \\ URL: http://dx.doi.org/10.5539/jsd.v6n11p122
}

\begin{abstract}
This paper attempts to determine the impact of research and development (R\&D) expenditure on the financial sustainability of the IT industry as represented by the IT companies listed on the S\&P 500 index. The impact of $R \& D$ expenditure on the intermediate variables of marketing performance, gross margin and technological performance is first ascertained. Further, the impact of each of these intermediate variables on financial sustainability, i.e. the return on assets (ROA), is determined. The empirical result shows that financial sustainability is most strongly affected by gross margins, which in turn are strongly impacted on by R\&D (Note 1) intensity. R\&D expenditure has a positive impact on sales revenues but a negative impact on technological performance. However, technological performance has a positive impact on financial sustainability. The non-availability of the decomposition of $\mathrm{R} \& \mathrm{D}$ expenditure in the annual reports of these companies poses a limitation to our research. Further, the impact of the time lag between the point at which R\&D expenditure is incurred and the point at which it starts to contribute to financial sustainability varies from firm to firm, thereby making it difficult to ascertain the impact of R\&D on financial sustainability. However, the results from our study pinpoint a very significant relationship between $R \& D$ intensity and gross margins. This also forms the backbone of the pricing strategy formulated by IT companies. Further, there is a very significant relationship between gross margins and financial sustainability, which is measured by ROA (Note 2).
\end{abstract}

Keywords: marketing, technology, $R \& D$, financial sustainability, return on asset, gross profit, patent

\section{Introduction}

The impact of research and development expenditure (hereinafter referred to as "R\&D expenditure") on financial sustainability has been the subject of research in the past (Artz et al., 2010; Hart \& Ahuja, 1996). However, the findings from these studies are mixed. The reasons for these mixed results vary, ranging from differences in the definitions of R\&D expenditure (Note 3) and financial sustainability to differences in whether and to what extent the relationship between R\&D expenditure and financial sustainability is defined directly or indirectly. Variations in the methodology used for conducting the research may also be a cause of these mixed results.

The definitions of R\&D expenditure vary. Research and development expenditure includes current and capital expenditure (private as well as public) on creative work that is conducted systematically to increase knowledge of humanity, society and cultures - and the use of this knowledge in new applications ("Research and development expenditure," n.d.). R\&D covers basic and applied research as well as experimental development. From this definition, it is evident that $R \& D$ expenditure is inclusive of current as well as capital expenditure. This poses a challenge to researchers studying the R\&D expenditure of any industry as a whole. Generally, one would find a firm's R\&D expenditure in its income statement, but due to inconsistencies between various reporting standards, they can also be capitalized in the balance sheet. Therefore, there are incongruities regarding what should be expensed and what should be regarded as an asset. An industry is composed of a number of companies - each of which could present its $R \& D$ expenditure differently. The R\&D expenditure might be inclusive of current expenditure, capital equipment costs and allowable depreciation expenditure. 
Another challenge is the lack of availability of the decomposition of R\&D expenditure in companies' annual reports. Not reporting the operating margin results in sufficient detail makes it extremely difficult to relate R\&D indices precisely to profitability measures (Scherer, 2001).

Sher and Yang (2005) define R\&D intensity as one of the variables affecting firm performance. They define $R \& D$ intensity as the ratio of R\&D expenditure to the total number of employees. On the other hand, Hart and Ahuja (1996) take the ratio of R\&D expenditure to sales as one of the independent variables as a determinant of firm performance. The research by Shin et al. (2009) and Ural and Acaravci (2006) also confirms the ratio of $R \& D$ expenditure to sales as one of the variables that determine firm performance.

The existence and impact of variables other than R\&D expenditure and their impact on financial sustainability also need to be acknowledged. Gilman and Miller (1978) state that corporate performance depends on many factors besides research. They also indicate that the relationships that actually do exist tend to become obscured.

'Sustainability' now often refers to the "three pillars" of sustainability, i.e. environmental, social and economic sustainability (Adams, 2006). These three sustainability pillars are mutually reinforcing and not mutually exclusive ("Sustainability", n.d.).

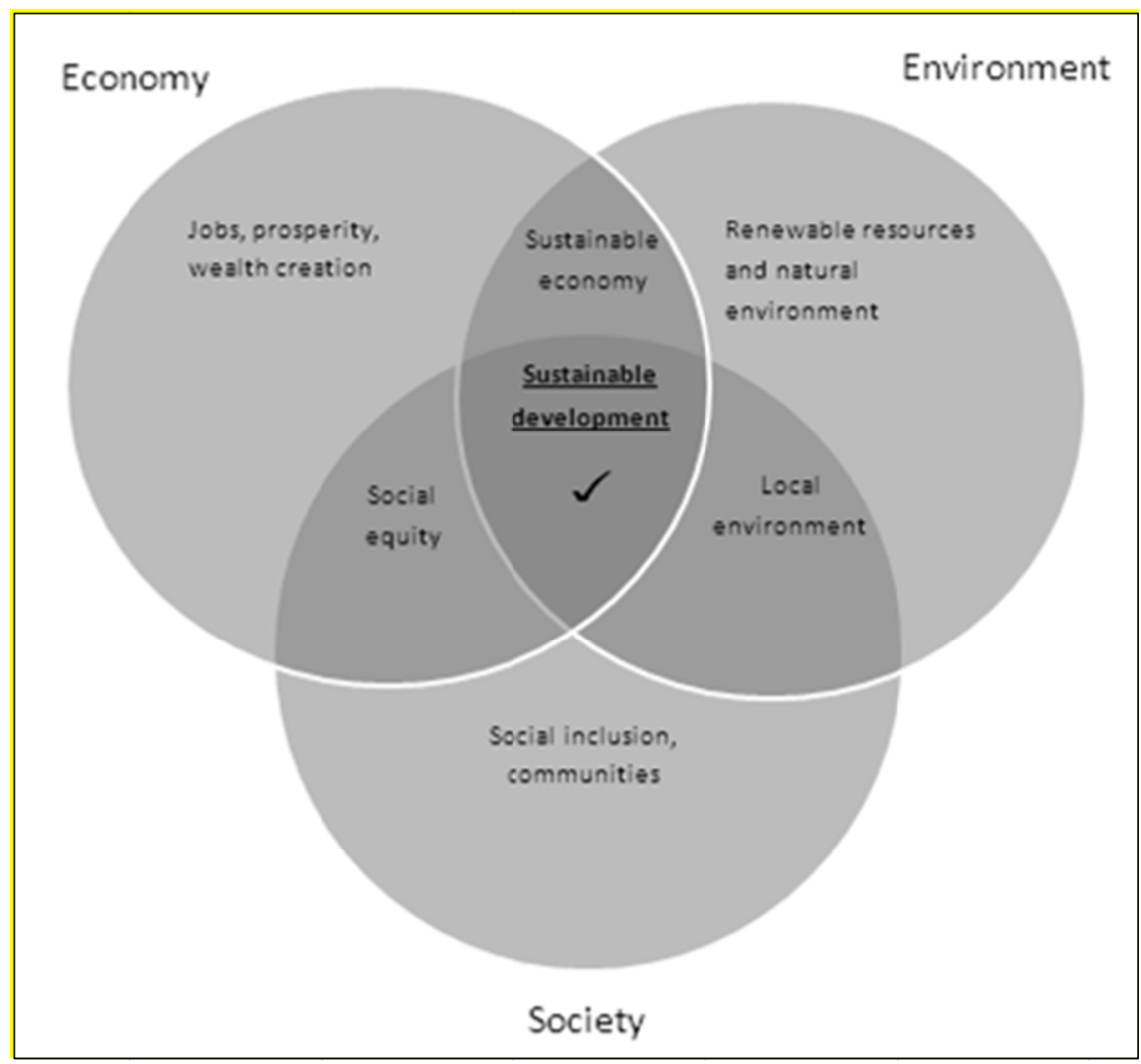

Figure 1. The interlinking themes of environment, economy and society that contribute to sustainable development

Source: Sustainability. (n.d.).

A business is socially responsible towards society in terms of environmental and social sustainability. Adam Smith, in his book An Inquiry into the Nature and Causes of the Wealth of Nations (1776), states that the interests of the society as a whole are served by the self-seeking actions of individuals. While environmental and social sustainability are important pillars, in order to attain both of them a firm needs funds and these funds can be realized only when the pillar of economic sustainability has been achieved. Milton Friedman, in his book Capitalism and Freedom (1962), writes that "... there is one and only one social responsibility of business - to use its resources and engage in activities designed to increase its profits so long as it stays within the rules of the game, which is to say, engages in open and free competition without deception or fraud". Thus, Friedman criticized the view of social responsibility on the grounds that any good other than profit maximization is bad for 
the company. It can result in misallocation of resources. Once profits have been generated to achieve financial sustainability, attempts to discharge social responsibility that are consistent with the shareholders of the business can be made.

Another key question is that of selecting the appropriate metric to determine financial sustainability. Hart and Ahuja (1996) use the ROA (return on assets), ROS (return on sales) and ROE (return on equity) as the determinants of firm performance. Artz et al. (2010) use the ROA and sales growth as measures of firm performance. Mokhtar et al. (2005) use nine different measures of corporate performance, of which they find the ROA (return on assets), EVA (economic value added) and industry category to be the most significant determinants of corporate performance. Hunton et al. (2003) use the ROA (return on assets), ROS (return on sales), ROI (return on investments) and ATO (asset turnover) as metrics of firm performance.

Besides the above metrics, there are certain other variables that are used to assess firm performance. Altinkemer et al. (2011) use labor productivity, i.e. the ratio of sales to the number of employees, inventory turnover and Tobin's Q, i.e. the ratio of the total market value of the firm to the total asset value to determine firm performance, besides ROA (return on assets) and ROE (return on equity). Verbeeten and Vijn (2010) measure performance by using the return on investment (ROI) or cash flow return on investment (CFROI). Fang et al. (2011) use the respective month's stock return for the same, whereas Pauwels et al. (2004) use the firm revenues, incomes, firm value and ratio of market capitalization to book value.

For our research, we have chosen the ROA (return on assets) as a measure of financial sustainability. The primary aim of our research is to examine the relationship between the $R \& D$ expenditure of information technology companies (hereinafter referred to as "IT companies") listed on the S\&P 500 index and its impact on financial sustainability (measured by the ROA (return on assets)). First, we examine the relationship of R\&D expenditure with the marketing performance, gross margin and technological performance of these IT companies; then, we examine the impact of each of these performances on the ROA (return on assets), which is our metric for determining financial sustainability.

\section{The IT Industry in the USA}

During the last two decades, information technology (IT) has been a key driver of innovation in many areas and has drastically changed social behavior across the world. In the past two years, manufacturing in the IT industry has been extremely volatile, with leading companies like Google, Motorola, Nokia, Microsoft, Apple and Hewlett-Packard making major changes to their commercial strategies due to the introduction of new products arising from their R\&D decisions as well as those of their competitors.

From the examples of these companies, we can say that success in the IT marketplace cannot be sustained merely by being the leader in terms of market share; it is also necessary to invest in research and development.

The IT industry is highly competitive as it is driven by new and rapidly changing technologies. IT companies typically rely heavily on trade secrets, patents and confidentiality and licensing agreements to establish proprietary technology and new product innovations as well as to protect them. In order to develop new products regularly, a company must typically sustain high levels of R\&D expenditure, resulting in constantly increasing costs. While this expenditure is essential in developing technologically advanced products to maintain a competitive advantage, what needs to be ascertained is whether this expenditure improves the financial sustainability of the company in terms of the ROA (return on assets).

The US ranks first overall in ICT, i.e. information and communication technologies (Finland is second), first in ICT R\&D (Israel is second) and first in human capital (China is second). It is a close second to Australia in the ICT legal environment and first in the IT industry environment (for which Canada comes second). However, the US is ninth in terms of IT infrastructure ("Investment for the Future - Benchmarking IT Industry Competitiveness 2011", n.d.).

Almost $70 \%$ of all global ICT R\&D investments are made by the US and Japan. With around $\$ 9$ billion in R\&D spending, Microsoft is the leader in ICT R\&D spending (Grueber \& Studt, 2011). 
Table 1. Top 10 ICT companies in the US based on R\&D expenditure

\begin{tabular}{lccc}
\hline Information and Communication Technologies & $\mathbf{2 0 0 9}$ & $\mathbf{2 0 1 0}$ & $\mathbf{2 0 1 1}$ (Q1 to Q3) \\
\hline Top US R\&D expenditures & \multicolumn{3}{c}{ Millions, US \$ } \\
\hline Microsoft & 8581.00 & 8951.00 & 6991.00 \\
Intel & 5653.00 & 6576.00 & 6042.00 \\
International Business Machines & 5820.00 & 6026.00 & 4702.00 \\
Cisco Systems & 4994.00 & 5711.00 & 4371.00 \\
Oracle & 2775.00 & 4108.00 & 3347.00 \\
Google & 2843.00 & 3762.00 & 3864.00 \\
Hewlett-Packard Co. & 2768.00 & 3076.00 & 2440.50 \\
Qualcomm & 2432.00 & 2624.00 & 2348.00 \\
Apple & 1416.00 & 1959.00 & 1854.00 \\
EMC & 1627.50 & 1888.00 & 1589.00 \\
\hline
\end{tabular}

Source: 2012 Global R\&D funding forecast (2011).

Thus, $R \& D$ spending is beginning to constitute a major share of the total spending of IT companies, which is why it is essential to examine whether it improves the ROA of the company or not.

\subsection{The S\&P 500 Index}

The S\&P 500 is an index of the prices of 500 large-cap common stocks actively trading in the United States. The stocks included in the S\&P 500 trade on the New York Stock Exchange or NASDAQ - two of the largest American stock market exchanges.

After the Dow Jones Industrial Average, the S\&P 500 is one of the most commonly followed equity indices. Many different kinds of funds, such as mutual funds, ETFs (exchange-traded funds) and pension funds are designed in such a way that they track the performance of the S\&P 500 index.

The S\&P 500 refers not just to the index, but also to the 500 companies that have their stocks included in the index. The stocks included in the S\&P 500 index are also part of the wider S\&P 1500 and S\&P Global 1200 stock market indices.

Companies included in the S\&P 500 are broadly classified into ten different industries:

(1) Industrials

(2) Financials

(3) Health care

(4) Consumer discretionary

(5) Information Technology (IT)

(6) Utilities

(7) Materials

(8) Consumer staples

(9) Energy

(10) Telecommunications services

The computing and electronics industry (also known as the IT industry) achieved the biggest absolute increase in R\&D spending in 2010 , accounting for $28 \%$ of the total R\&D expenditure. The health-care industry came second, with a $22 \%$ share in $R \& D$ spending (Corporate R\&D spending, 2011). Since the IT industry has the highest $\mathrm{R} \& \mathrm{D}$ spending, it is necessary to analyze the productivity of this spending and its impact on financial sustainability.

Six IT majors (from all the IT companies listed on the S\&P 500) form more than half of the industry sales. This can be seen from the table below. 
Table 2. Percentage of sales from the top six US IT companies (Figures in '000s)

\begin{tabular}{lcc}
\hline Company Name & Sales (in \$) & $\begin{array}{c}\text { Percentage of } \\
\text { Industry Sales }\end{array}$ \\
\hline HP & 126033000 & $15.71 \%$ \\
IBM & 99870000 & $12.45 \%$ \\
Apple & 65225000 & $8.13 \%$ \\
Microsoft & 62484000 & $7.79 \%$ \\
Dell & 52902000 & $6.59 \%$ \\
Intel & 43623000 & $5.44 \%$ \\
Total sales of top six IT companies on S\&P 500 & $\mathbf{4 5 0 ~ 1 3 7 ~ 0 0 0}$ & $\mathbf{5 6 . 1 0 \%}$ \\
Total sales of sixty IT companies on S\&P 500 & $\mathbf{8 0 2} \mathbf{3 6 1} \mathbf{2 9 1}$ & $\mathbf{1 0 0 \%}$ \\
\hline
\end{tabular}

Source:

(i) Income Statement of Hewlett Packard Co. Retrieved from Thomson Reuters Eikon database on 28th February, 2012

(ii) Income statement of International Business Machines Corp. Retrieved from Thomson Reuters Eikon database on 25th February, 2012

(iii) Income statement of Apple Inc. Retrieved from Thomson Reuters Eikon database on 17th February, 2012

(iv) Income statement of Microsoft Corp. Retrieved from Thomson Reuters Eikon database on 25th February, 2012

(v) Income statement of Dell Inc. Retrieved from Thomson Reuters Eikon database on 25th February, 2012

(vi) Income statement of Intel Corp. Retrieved from Thomson Reuters Eikon database on 25th February, 2012

\subsection{Prior Research and Literature Review}

The survey of literature served two purposes for us. First, it justified our choice of dependent and independent variables. Second, it gave us some insight into the existing research about this topic and the methods used for the same.

We have used financial ratios to determine the impact of $R \& D$ expenditure on financial sustainability. This approach of ours is supported by Feng and Wang (2001). However, there are researches which take into account qualitative variables such as knowledge oriented motives, market oriented motives and resource oriented motives also (all measured on Likert scales) as performance measures (Arvanitis \& Hollenstein, 2011).

As far as our choice of ROA (Return on Assets) as a measure of financial sustainability is concerned, we have supporting literature for the same (He \& Huang, 2011). Lo et al. (2012) use ROA (Return on Assets) and ROS (Return on Sales) as determinants of financial performance. Wang and Qian (2011) use ROA (Return on Assets) and market to book ratio as measures of financial performance. Rothschild (2006) states that ROA is the most critical financial goal for manufacturing firms.

As far as our choice of independent variables is concerned, we have literature supporting our choice of R\&D intensity (i.e. the ratio of R\&D expenditure to sales) as the independent variable (Shin et al., 2009; Ural \& Acaravci, 2006).

R\&D expenditure does have an impact on sales growth (Franko, 1989; Kenneth Ko, 2005; Chang \& Su, 2010; Morbey, 1988). There is a significant correlation between sales growth and R\&D intensity in the base metal chemical industry (Shirsendu Ganguli, 2009). Sales growth is an indicator of marketing effectiveness (Basuki \& Henderson, 2003).

Regarding the impact of R\&D expenditure on profitability, Lewin and Chew (2005) state that high spending on $R \& D$ is not a guarantee of high profitability unless firms manage it properly. R\&D expenses affect profitability estimates of businesses because R\&D expenditure is required to be expensed immediately. The profitability in turn distorts the ROA (Danielson \& Press, 2005) which is why we haven't examined the relationship between R\&D expenditure and ROA directly. The distortion can be proved by our findings on the impact of R\&D intensity to ROA directly for all the 60 IT companies in our sample and for the six major IT companies - IBM, 
Dell, Microsoft, HP, Apple and Intel. The path co-efficient for relationship between R\&D intensity and ROA for all 60 companies is negative (path co-efficient $=-0.170$ and t-statistic $=2.53$ ) while the path-coefficient for the same for the six IT majors, as stated above, is positive (path co-efficient $=0.220$ and t-statistic $=2.14$ ).

We have used regression analysis for our study. This is supported by the research of Mithas (2012), Zhang and Rogers (2009), Cronin and Cronin (1985) and Mittal (2004).

Past research which examines the impact of R\&D expenditure on ROA has given varied results. As per Altinkemer et al. (2011), ROA drops significantly in the project initiation year. Various performance and productivity measures improve in a decreasing manner after the initiation year due to fixed effects regression.

According to Pauwels et al. (2004), introducing new products increases long term financial performance and firm value. Product entry in new markets gives the highest top-line, bottom-line and stock market benefits. Firm revenue, firm income, firm value and the ratio of market capitalization to book value have been used as metrics for financial sustainability in their study. Artz et al. (2010) state that R\&D spending is positively related to patents but there is a negative relationship between patents and ROA and patents and firm growth. However, there is a positive relationship between patents and new product announcements. Sher and Yang (2005) observe that innovative capabilities are generally positively related to performance measured in terms of ROA (Returns on Assets).

Hunton et al. (2003) observe that ROA (Return on Assets), ROS (Return on Sales) and ATO (Asset Turnover) is significantly lower for non-ERP (Enterprise Resource Planning) adopters than for ERP adopters in the third year after ERP implementation. Pandit et al. (2011) measure firm performance in terms of net income and operating cash flows. They find that the mean level of future operating performance is positively associated with the quality of a firm's patents. The standard deviation of future operating performance is negatively associated with the quality of the firm's patents and more innovative firms have higher levels of operating performance and lower levels of uncertainty in terms of operating performance.

However, a research gap that we faced was the limited amount of research conducted to measure the impact of R\&D expenditure on technological performance. A further gap consisted of the limited research carried out to ascertain the impact of marketing performance, gross margins and technological innovation on financial sustainability. The primary aim of our research is to bridge this gap.

\subsection{Research Objective and Methodology}

The objective of the study was threefold: (1) to determine the impact of R\&D expenditure on the financial sustainability of IT companies (measured by ROA) through three performance measures - marketing performance, gross margin and technological performance, (2) to develop a model that captures the indirect relationship between the R\&D expenditure and the financial sustainability of IT companies through the above-mentioned measures and (3) to determine the extent of the relationship between the R\&D expenditure, the performance measures and the financial sustainability of IT companies.

This paper presents how R\&D expenses impact on the financial sustainability of companies, taking the IT industry of the USA as a sample. We then developed a model that captures the relationship between the R\&D expenditure and the financial sustainability of companies through three intermediating performance measures marketing performance, gross margin performance and technological performance.

To test the relationship implied by the research model and the research hypothesis, this study used secondary sources for data collection. The first step in the data collection involved identifying the IT companies listed on the S\&P 500 index as of February 6, 2012. This gave us a sample of seventy companies. The sample was to be analyzed for a period of ten years, i.e. 2001-2010. The second part of the data collection involved identifying ratios to measure each of the identified parameters, i.e. research and development, marketing performance, gross margin, technological performance and financial sustainability (represented by the ROA). For this, a random selection of annual reports of a few IT companies was studied. After identifying the ratios, we added some filters to the sample in order to avoid biases. We removed the companies that did not have $R \& D$ expenses for more than two years out of the ten years. This process reduced our sample size to sixty-two companies. We could not find sufficient financial information for two of these companies since they were merged with other companies within the sample itself. Finally, our sample consisted of sixty companies for ten years. After collecting the financial information of the sample companies from Thomson Reuters, we calculated the identified ratios for all the sixty companies for ten years. Thomson Reuters presents the income statement, balance sheet and cash flow statements of companies as they are reported. The ratios that we calculated are as follows:

- $\quad R \& D$ expenditure/sales 
- R\&D YoY (year-on-year) growth

- Sales YoY (year-on-year) growth

- Sales/non-current assets

- Gross margin

- Return on assets

- Return on assets YoY (year-on-year) growth

Wheelen and Hunger (2002) define performance simply as the end result of activity. The marketing performance parameter measures the end result of investing in R\&D activities in terms of sales. Ambler and Kokkinaki (1997) review articles relating to marketing performance measures and find that the top three measures are sales and sales growth, market share, and profit contribution and brand preference - both in third place. This supports our argument for the use of sales growth as a measure of marketing performance.

Significant research has been performed using R\&D intensity as a measure of the R\&D parameter (Leonard, 1971). The research intensity of a firm signifies its commitment to science and technology as a means of effecting growth through change. It can be represented by the ratio of R\&D inputs to current output, the most common measure being $R \& D$ expenditure as a proportion of sales. However, to measure sales growth (which is the dependent variable), it is important to use a growth measure for the independent variable. We used change in R\&D YoY as the independent variable when the impact of R\&D was tested on marketing performance.

Based on a working paper by the National Bureau of Economic Research - Measuring the Returns to R\&D (2009) - there is a significant relationship between the gross margin and the R\&D spending of a firm. The gross margin percentage is the gross profit to sales ratio, where the gross profits are the sales less the cost of the goods sold, and are therefore gross of $R \& D$ expenditure. This fact implies that there will be a simple accounting correlation between the gross profit to sales ratio and the R\&D to sales ratio and we expect the relationship to be positive, with any increase in the R\&D matched by an increase in the gross profits. The relation basically tests the returns to scale based on R\&D spending. Even Susan Holak et al. (1991) state that increased R\&D spending can have either a positive or a negative influence on the gross margin. This relation is also tested with our model.

In the third part of our model, we test the relation between the R\&D and the technological performance of the firm. By means of the technological performance, we intend to test the operational efficiency of the firm. Some of the measures of operating efficiency and factors that explain efficiency could be tested by the fixed assets-turnover ratio, measured by sales to fixed assets (Qudah, 2011). This indicates the extent to which long-term assets are used to produce sales (Robinson et al., 2003). In the same context, Gibson (1989) writes that the sales to fixed assets ratio measures the firm's ability to make productive use of its property, plant and equipment through the generation of sales dollars. So, the more efficiently assets are used, the higher a firm's profits, where (fixed assets $=$ property + plant + equipment). However, after analyzing the annual report of some of the companies, we realized that various other intangibles, like patents, goodwill and trademarks, would not be captured even though they significantly influence the sale of the company. Hence, we decided to take the denominator of the asset turnover ratio as the non-current assets (non-current assets $=$ total assets - current assets) instead of just the fixed assets to capture the intangible assets.

In the next stage of the model, the earlier dependent variable becomes the independent variable and the impact is tested on the financial sustainability of the firm. The sustainability of a firm depends on its financial performance. The financial performance is measured using the return on assets (ROA) (Waddock \& Graves, 1997).

While comparing the marketing performance of the company with its financial sustainability, we use the ROA YoY growth, because we believe that a growth-dependent variable should be used against a growth-independent variable. ROA growth is the ratio of gross operating profits to assets between the current year and the preceding year.

In the next step of the model, we test the degree to which gross margins have an impact on the financial sustainability of the firm, i.e. ROA. The ROA is measured as the net income (PAT) to total assets and can be calculated as (net income/total assets) $* 100$.

In our final test of the model, we determine the relationship between the technological performance of the company, which is measured by the non-current asset turnover (i.e. sales/non-current assets), and the financial sustainability of the firm, which is measured by the ROA. The efficiency of the management of a firm can be measured by the way and manner in which they utilize the assets of the firm to yield positive returns. The asset 
turnover ratio is an important financial ratio that can be used to achieve the purpose of measuring management efficiency (Onaolapo \& Kajola, 2010).

The limited literature on marketing performance and financial sustainability as well as the gross margin and financial sustainability constitute a research gap for our study.

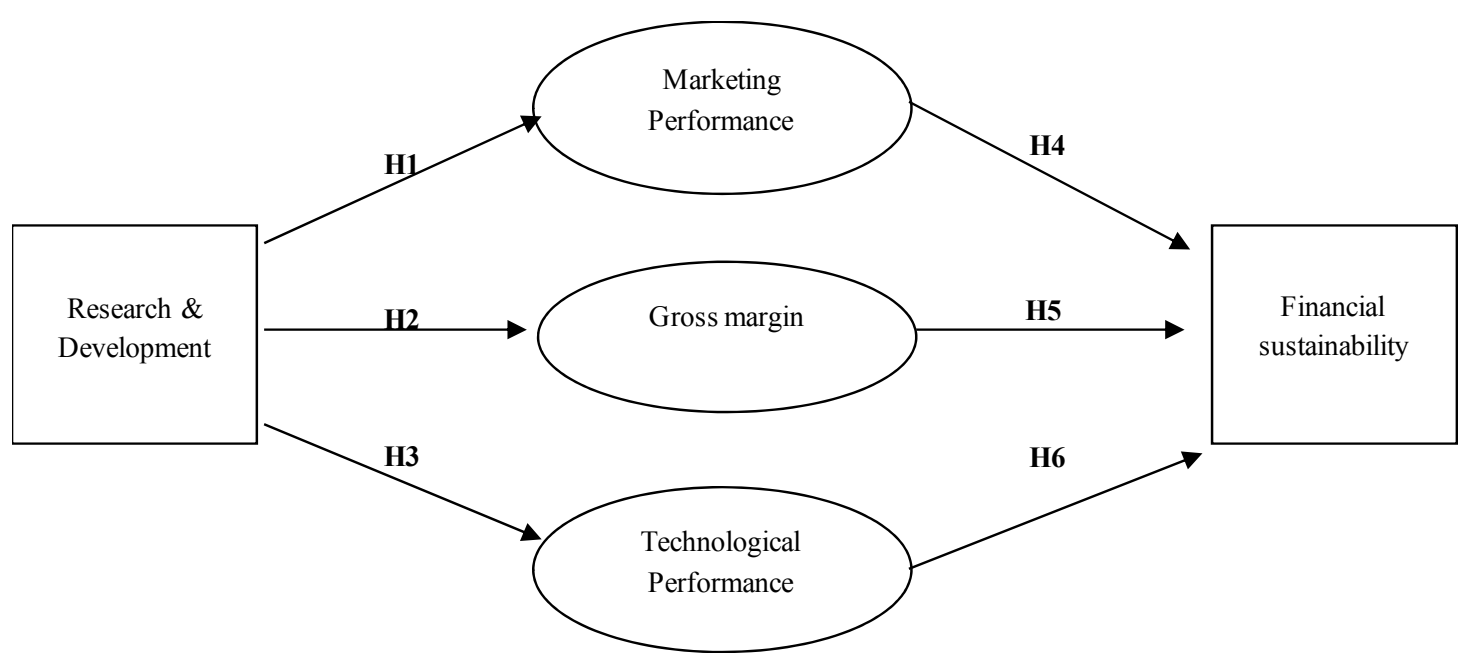

Figure 2. Proposed model

\subsection{Hypothesis}

H1 - There is significant relationship between R\&D expense and Marketing performance of IT companies.

Companies invest in research and development with the hope that this spending will actually be investment for the companies that increase sales of the company. As stated earlier, marketing performance is measured by sales growth and $R \& D$ is captured by change in $R \& D$ expense growth. Sales growth is an indicator of firm growth and it is expected that this will be correlated with R\&D investment (Hall et al., 2009). Based on a study conducted by Artz et al. (2010), there is a negative relation between $R \& D$ and sales growth of a firm.

H2 - There is significant relationship between R\&D expense and Gross margin performance of IT companies.

There is a possibility that firms are investing in research activities that help improvise their gross margin by innovating technology that allow firms to use cheaper alternatives to manufacture. According to a study conducted by Booz Allen Hamilton, the only statistical relationship identified was that R\&D spending appears to yield better gross margins (Jaruzelski, Dehoff, \& Bordia, 2005). The relationship between R\&D intensity and current profitability is more variable (Hall et al., 2009).

H3 - There is a significant relationship between R\&D expense and Technological performance of IT companies.

As the R\&D intensity increases, there is a possibility that firms may have to patent their innovation. As a result of this, their asset base (particularly of intangible assets such as patents) may increase. The assets of firms may also increase due to addition of capacity to cater to the increasing demand.

H4 - There is a significant relationship between marketing performance and financial sustainability of IT companies.

Ideally it is expected that with an increase in the sales revenues of a company, the return on assets of companies should improve. However, for IT companies whose sales revenues have increased, the asset base is also likely to increase as a result of which the ROA of a company may come down even though the net income may have gone up.

H5 - There is a significant relationship between gross margins and financial sustainability of IT companies.

Gross margins of companies can expand for two reasons. First, if firms are able to increase sales without proportionally increasing the variable expenses (Luckham, 1982). The other possibility is that firms are able to make the same sale with a lower value of variable expense or customers are willing to pay a higher per-unit price for the firm's products (Byus et al., 2010). With the improvement in gross margins, it is expected to positively 
impact the financial sustainability of the firm. This hypothesis tests whether there is a significant relationship between gross margin and financial sustainability.

H6 - There is a significant relationship between technological performance and financial sustainability of IT companies.

Asset turnover (Sales/Total assets) when multiplied by the net profit (Net profit/Sales) margin yields the return on assets (Luckham, 1982). Based on this, it is expected that there is a positive relationship between asset turnover and return on asset.

\subsection{Data Analysis}

We have used partial least squares (PLS) to validate and measure our hypotheses. PLS employs a component-based structure equation modeling (SEM) rather than a co-variance based SEM which makes the PLS algorithm usable even for small sample sizes (Chin, 1998). PLS helps avoid two problems: inadmissible solutions and factor indeterminacy (Fornell \& Bookstein, 1982), which makes it best suited for complex models. PLS estimates both formative and reflective constructs. Hence, we chose the PLS model due to our small sample size, simple estimation of results and practical meaning of factor scores.

\section{Method of Analysis}

The hypothesis testing was done on the basis of two parameters: the path coefficients and the t-value. After running the model in SMART -PLS for the PLS algorithm we found out the path coefficients of the dependent variables to the independent variables. This gave us the relationship between them. If the coefficient is positive, the two variables have a direct relationship and if it is negative, they have an inverse relationship.

After running the PLS algorithm, we ran the Bootstrapping algorithm to find out the t-statistic value of the different relationships in the model. For our research, we have taken $99 \%$ as the confidence interval which means the t-stat $>2.58$ and $p<0.01$ (Vasilopoulos, 2011) for the relationship to be significant.

\section{Results}

We tested our model (Figure 2) in two parts. In the first part, we tested Research and Development with the marketing performance, the gross margin and the technological performance. We got a positive and significant relation between year-on-year increase in $R \& D$ expenditure and marketing performance $(b=0.560, p<0.01)$ (Leonard, 1971). We also observed a significant positive relationship between R\&D intensity and gross margins $(b=0.236, p<0.01)$. However, we observed a negative and significant relation between R\&D intensity and technological performance $(b=-0.150, \mathrm{p}<0.01)$.

In the second part, we tested the marketing performance, the gross margins and the technological performance respectively to return on assets, where we find that there is a positive and significant relationship between technological performance and ROA $(b=0.124, p<0.01)$. There is also a significant and positive relationship between gross margins and ROA $(b=0.274, p<0.01)$. There is an insignificant relationship between marketing performance and ROA $(b=0.050, p>0.01)$ i.e. return on assets which leads to a rejection of $\mathrm{H}_{4}$.

\section{Discussion}

The results demonstrated a significant indirect relationship between $R \& D$ expense and financial sustainability through gross margin.

\section{$5.1 R \& D$ and Marketing Performance}

The relationship between R\&D and marketing performance is measured by year on year changes in R\&D expenditure and year on year changes in sales growth. The significant positive relationship indicates that with an increase in R\&D expenses, the sales of IT companies are growing. A possible explanation for this positive relationship is that as companies innovate new products and manufactures them, their revenues go up. This rise in revenues is volume driven. i.e. it rises because of increase in demand. The prices of these new products mostly remain the same as their predecessors or may be marginally higher. Companies cannot increase the prices of their products significantly because of the high intensity of competition in the industry. For e.g.: When Apple launches a new version of iphone, the price of the new iphone is more or less the same as its predecessor. If Apple increases the price of the new iphone significantly, then it is likely that it may lose out on sales to its competitors who sell similar technology phones at a relatively lower price.

\section{$5.2 R \& D$ and Gross Margin}

The relationship between $R \& D$ and gross margin was tested using $R \& D$ intensity (i.e. R\&D / Sales ratio) and gross margin (i.e. gross profit/sales). On running the model, a significant positive relationship was observed 
between R\&D and gross profit margin. Companies with higher R\&D intensity are expected to have a higher gross profit margin. The rationale behind this is that companies may be investing in research projects that help them reduce the cost of materials and labor used in their manufacturing processes. Gross margin measures profit from sale after accounting for material, labor and other manufacturing costs. A reduction in material and labor costs leads to a rise in gross profit margin. Another possibility is that the R\&D teams of companies have been successful in innovating products that enable them to differentiate their products in terms of quality and ease of use from their competitors. This in turn allows them to charge a slightly higher price which further improves the gross margin of the company.

\section{$5.3 R \& D$ and Technological Performance}

The relation between $R \& D$ and technological performance is tested using $R \& D / S a l e s$ ratio and Sales/Non-current asset ratio respectively. On testing the model we found a significant negative relationship between R\&D and technological performance. This can be explained by the expanding non - current asset base due to discovery of new technology. As and when companies develop new technologies, they register them as patents. These patents become a part of the company's intangible asset base. The negative relationship between $R \& D$ intensity and technological performance can be explained by investment in intangibles for protecting existing technologies from competitors rather than for actual innovation (Artz et al., 2010). These intangibles don't contribute to innovation or rise in revenues in any way and increase the non-current asset base thereby leading to a decline in the ratio of sales to non-current assets. For e.g. Google acquired Motorola for its portfolio of patents which would help them defend Android against legal threats from competitors armed with their own patents (Erica Naone, 2011).

Table 3. Results of hypothesis testing for sixty companies

\begin{tabular}{clccc}
\hline \multicolumn{5}{c}{ 60 IT companies } \\
\hline Hypothesis & Hypothesis tested & Co-efficient & t-statistic & Accepted/Rejected \\
\hline H1 & R\&D to Marketing Performance & 0.56 & $11.50^{* *}$ & Accepted \\
H2 & R\&D to Gross margin & 0.236 & $4.55^{* *}$ & Accepted \\
H3 & R\&D to Technological Performance & -0.15 & $5.81^{* *}$ & Accepted \\
H4 & Marketing performance to Financial & 0.05 & 1.14 & Rejected \\
& sustainability & & & \\
H5 & Gross Margin to Financial sustainability & 0.274 & $5.96^{* *}$ & Accepted \\
H6 & Technological performance to Financial & 0.124 & $4.40^{* *}$ & Accepted \\
& sustainability & & & \\
\hline
\end{tabular}

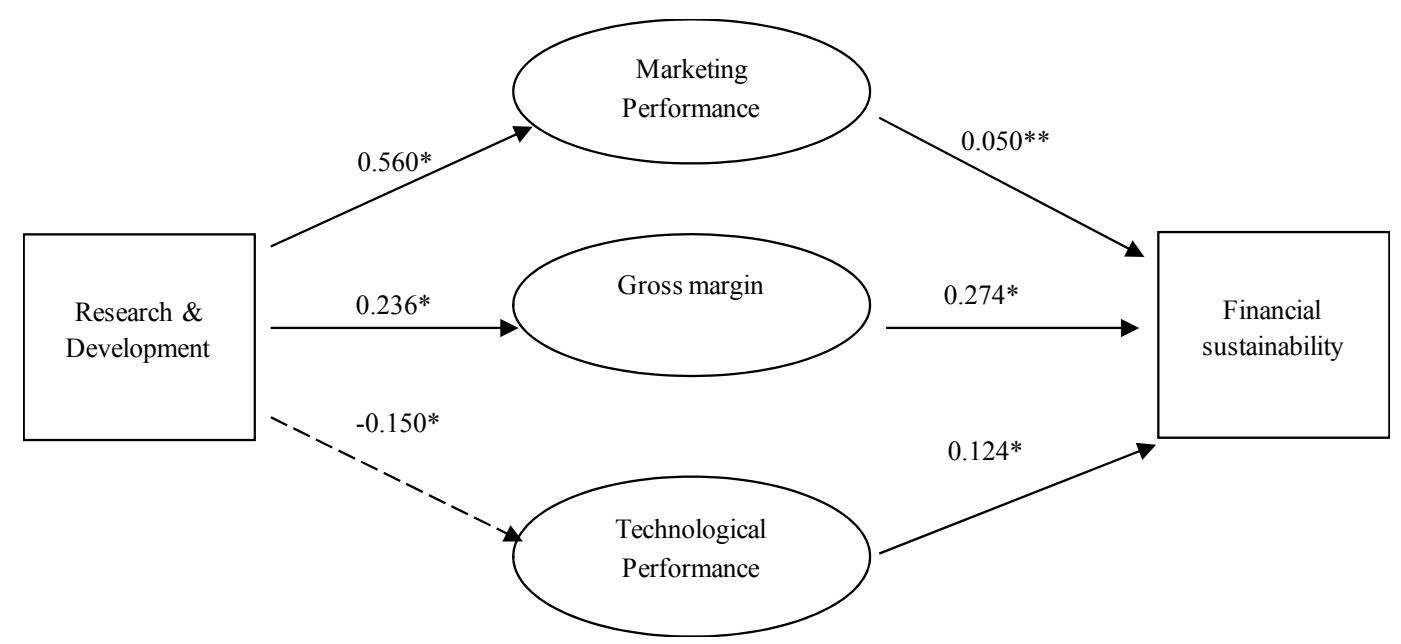

Figure 3. Results of analysis

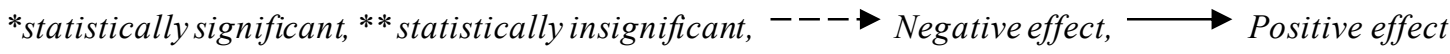


We also tested this model on the top six IT companies based on revenues - Apple, Dell, IBM, HP, Intel and Microsoft to see if this negative relationship was applicable to them as well. On running the model, we observed a similar significant negative relationship between $R \& D$ and technological performance for these companies (path co-efficient $=-0.562$, t-statistic $=9.50$ ). This supports the negative relationship between $\mathrm{R} \& \mathrm{D}$ and technological performance established by our model.

\subsection{Marketing Performance and Financial Sustainability}

The relation between marketing performance and financial sustainability is measured using year on year growth in sales and year on year change in return on asset. There is a positive relationship between marketing performance and financial sustainability but it is very insignificant. This means that there is no definite relationship between marketing performance and financial sustainability.

\subsection{Gross Margin and Financial Sustainability}

The impact of gross margins on financial sustainability is measured using gross profit ratio and return on asset respectively. Running the model shows a significant positive relation between gross margin and financial sustainability. It is reasonable to expect that with an improvement in gross margin, return on assets of a company would improve. This can be explained by economies of scale. As the sales of companies increase, the average cost per unit decreases. This is mainly due to two factors. First, as sales increases the bargaining power of companies also increase in terms of obtaining lower prices from suppliers for bulk raw-material and component purchases. Second, the fixed costs are spread over an increased number of units. So, with increase in sales, the phenomenon of economies of scale starts showing effect and improves the gross margin as well as ROA of companies.

\subsection{Technological Performance and Financial Sustainability}

The impact of technological performance on financial sustainability is measured using Sales / NCA ratio and ROA (Return on Assets). It is expected that there would be a positive relation between Sales / NCA and Return on Assets. This can be explained with the basic expansion of the ROA formula.

ROA $=($ Net profit / Sales) $x$ (Sales / Total assets)

We have used the Sales / NCA as our asset turnover ratio. NCA = Total Asset - Current Asset. There would be a close relation between Sales / Total asset and Sales / NCA. With the increase in Sales / Total asset, it is expected that Sales / NCA would also improve. This is because the denominator of Sales / NCA would be lower as compared to Sales / Total asset and therefore would result in a higher ratio. On testing the model as well we found a significant positive relation between Sales / NCA and ROA.

\subsection{Complete Model}

On viewing the model as a whole, we can say that there is a strong indirect positive relationship between R\&D and financial sustainability through the gross margin measure.

\subsection{Summary of Findings from Descriptive Statistics}

There is a significant positive relationship between the year-on-year changes in R\&D expenditure and the year-on-year changes in sales revenues (path co-efficient $=0.56$ and t-statistic $=11.50$ ). This is indicative of the fact that new innovations due to research and development lead to new product developments and hence higher sales volumes. This is turn contributes to the growth in revenue.

However, the relationship between year-on-year sales growth and financial sustainability, though positive, is very insignificant (path co-efficient $=0.050$, $\mathrm{t}$-statistic $=1.14$ ). This might be due to the typical nature of new product introductions in the IT industry. Prices of every new version of an existing product are almost the same as the previous version or only marginally higher. However, it would be packed with several improvised features over the previous version leading to higher costs and therefore, reduced margins. Reduced margins would lead to a lower ROA (Return on Assets).

$R \& D$ intensity (i.e. the ratio of $R \& D$ expenditure to sales) has a positive relationship with Gross Margins (i.e. the ratio of gross profit to sales). The path co-efficient is $=0.236$ and the t-statistic is 4.55 . Investments in R\&D help in improving methods of production thereby reducing the production costs - both in terms of material costs as well as labor costs by raising productivity, eliminating waste and rework etc. As stated in point (a) above, $R \& D$ expenditures have a positive impact on sales revenues. This growth in sales revenues is volume driven.

The relationship between gross margin and financial sustainability is also positive and significant (path co-efficient $=0.274$, t-statistic $=5.96$ ). There is an increase in the efficiency of production as the number of 
goods being produced increases. Generally, economies of scale lower the average cost per unit through increased production since fixed costs are shared over an increased number of goods.

The relationship between $R \& D$ expenditure and technological innovation (measured by the ratio of sales to non-current assets) is negative and significant (path co-efficient $=-0.150$, t-statistic $=5.81$ ). This can be explained by investment in intangibles for protecting existing technologies from competitors rather than for actual innovation. (Artz et al., 2010). These intangibles don't contribute to innovation or rise in revenues in any way and increase the non-current asset base thereby leading to a decline in the ratio of sales to non-current assets.

The relationship between technological innovation (i.e. the ratio of sales to non-current assets) and financial sustainability is positive and significant (path co-efficient $=0.124$, t-statistic $=4.40$ ). Financial sustainability as measured by ROA is a composite of two ratios i.e. net profit ratio and asset turnover ratio. Assuming no change in the net profit ratio, if the ratio of sales to non-current assets increases, the ROA would also rise.

From the study, it is apparent that R\&D expenditure has the maximum impact on gross margins and gross margins have the maximum impact on financial sustainability. Thus gross margin (which is positively related to R\&D expenditure) has the most significant positive impact on ROA as compared to marketing or technological performance. Gross margin also represents the pricing policy of the industry.

On conducting the same hypothesis tests for top six IT companies, we found similar results in all the tests except when we compared the Marketing performance to financial sustainability. There is a significant positive relation between marketing performance to financial performance for the top six companies, whereas there is an insignificant positive relation for the whole sample of sixty companies.

Table 4. Results of hypothesis testing for both sixty companies and top six companies in the IT industry

\begin{tabular}{clcccccc}
\hline & \multicolumn{3}{c}{ 60 IT companies } & \multicolumn{3}{c}{ Top 6 companies } \\
\hline & $\begin{array}{l}\text { Hypothesis } \\
\text { tested }\end{array}$ & Co-efficient & t-statistic & $\begin{array}{l}\text { Accepted/ } \\
\text { Rejected }\end{array}$ & Co-efficient & t-statistic & $\begin{array}{c}\text { Accepted/ } \\
\text { Rejected }\end{array}$ \\
\hline H1 & $\begin{array}{l}\text { R\&D to } \\
\text { Marketing } \\
\text { Performance }\end{array}$ & 0.56 & $11.50^{* *}$ & Accepted & 0.457 & $3.44^{* *}$ & Accepted \\
H2 & $\begin{array}{l}\text { R\&D to Gross } \\
\text { margin }\end{array}$ & 0.236 & $4.55^{* *}$ & Accepted & 0.895 & $44.73^{* *}$ & Accepted \\
H3 & $\begin{array}{l}\text { R\&D to } \\
\text { Technological } \\
\text { Performance }\end{array}$ & -0.15 & $5.81^{* *}$ & Accepted & -0.562 & $9.50^{* *}$ & Accepted \\
H4 & $\begin{array}{l}\text { Marketing } \\
\text { performance } \\
\text { to Financial } \\
\text { sustainability } \\
\text { Gross Margin } \\
\text { to Financial } \\
\text { sustainability }\end{array}$ & 0.05 & 1.14 & Rejected & 0.418 & $2.86^{* *}$ & Accepted \\
H6 & 0.274 & $5.96^{* *}$ & Accepted & 0.714 & $7.50^{* *}$ & Accepted \\
$\begin{array}{l}\text { Technological } \\
\text { performance } \\
\text { to Financial } \\
\text { sustainability }\end{array}$ & 0.124 & $4.40^{* *}$ & Accepted & 0.346 & $2.97^{* *}$ & Accepted \\
\hline
\end{tabular}

\subsection{Limitations and Scope for Further Research}

Our study has a few limitations. First, the decomposition of R\&D expenditure is not given in all the annual reports. In the absence of this data, it is difficult to determine how much R\&D expenditure pertains to a particular project, how much portion of it has long term effects on revenues and how much portion has short term effects on revenues. There might be R\&D expenditures which start showing effects only after a few years 
and not immediately. If the detailed breakup regarding these expenditures is available, their specific impact on revenues and ROA can be ascertained.

The lag effect of $R \& D$ expenditure can be examined. Many times, $R \& D$ expenditure incurred in a certain year starts showing effect only after a certain number of years. This comparison across different time periods is necessary to ascertain not just the effectiveness of $R \& D$ expenditure but also the time taken for its benefits to start showing.

Since the study covers only IT companies listed in the S\&P 500, it is a representative of the American IT industry. These conclusions cannot be applied to the IT industry of other countries directly because their operating and business environments may be different. The legal, social and cultural environment in which firms operate in other countries, particularly emerging nations may be significantly different from the American IT industry.

We could further have segregated the IT companies into sub-industries as per the Global Industry Classification Standard (GICS) - 'software and services', 'technology hardware and equipment' and 'semiconductors and semiconductor equipment.' This would've led to a more accurate assessment of R\&D expenditure's impact on ROA.

The ROA might be impacted by factors and variables other than the ones we have identified. With a higher number of variables identified in the model, changes in ROA might be explained in a better way.

\section{Conclusion and Implications of the Study}

The objective of the study was to determine the impact of R\&D expense on the financial sustainability of IT companies (measured by ROA) through three performance measures - Marketing Performance, Gross Margin and Technological Performance and the extent of relationship between R\&D expenses, performance measures and financial sustainability of IT companies. The second objective was to develop a model that captures the indirect relationship between R\&D expense and financial sustainability of IT companies through the above mentioned measures.

The selection of the independent variable, moderating variables and dependent variable was done after a survey of literature. The relationships between these variables were then examined using a regression model at $99 \%$ significance level. The results revealed that R\&D intensity positively impacts gross margins due to reduction in variable costs of production due to $R \& D$. Gross margins in turn positively impact the financial sustainability of IT companies as economies of scale lower the average cost per unit through increased production since fixed costs are shared over an increased number of goods. While R\&D expenditure leads to new product innovation and a consequent rise in volume driven sales revenues, the rising sales revenues have a very minor impact on the ROA due to the typical nature of new product introductions in the IT industry. Prices of every new version of an existing product are almost the same or only marginally higher than the previous version. Since it would be packed with several additional features over the previous version, it leads to higher costs and therefore, reduced margins. Reduced margins along with expanding asset base due to patents would result in a lower ROA (Return on Assets).

We thus conclude that gross margin is the variable that is most strongly affected by R\&D intensity and it is also the variable that most strongly influences the financial sustainability of IT companies.

IT companies can benefit from this analysis. It is clear that in order to survive and financially sustain their businesses, IT companies need to invest in Research and Development. Failure to do so will give their competitors a chance to seize their market share. While this R\&D does drive up sales revenues as seen in the model, rise in revenues does not lead to a significant rise in ROA. As mentioned earlier, this happens because most new models or improvisations over previous products are priced almost similar to the preceding versions/models. However, they come with many additional features which drive up their production cost leading to lower margins and lower ROA. When IT companies know this, they have two challenges on hand. First, R\&D would be necessary to increase sales. On the other hand, they need to control their cost structures so that they can allow this sales growth to drive up ROA. For this, they need to focus on R\&D expenditure not just to develop new products but also to devise means to reduce existing production costs. An IT company which can find out a way to balance both these goals can outpace its competitors.

The strongest relationship has been observed between $\mathrm{R} \& \mathrm{D}$ expenditure and ROA via the gross margin. The positive relationship between $R \& D$ expenditure and gross margin again confirms the fact that $R \& D$ expenditure when made to reduce production costs is beneficial to the firm. The positive relationship between gross margin and ROA emphasizes the importance of economies of scale. Understandably, considering the huge amounts of 
expenditure incurred on $R \& D$, companies need to plan production scales that are large enough to justify the amount of R\&D spending on them. This positive relationship would help Information Technology companies to frame realistic pricing policies which will improve their gross margin.

The negative relationship between $R \& D$ intensity and technological performance indicates that IT companies need to think whether they are investing too much in patents or intangibles just for protecting themselves against existing competition or legal disputes rather than focusing on innovation.

The new model is given below. From the diagram, it is evident that there is no significant relationship between marketing performance and financial sustainability. There is a negative performance between R\&D intensity and technological performance. There is a positive indirect relationship between R\&D intensity and financial sustainability via gross margins.

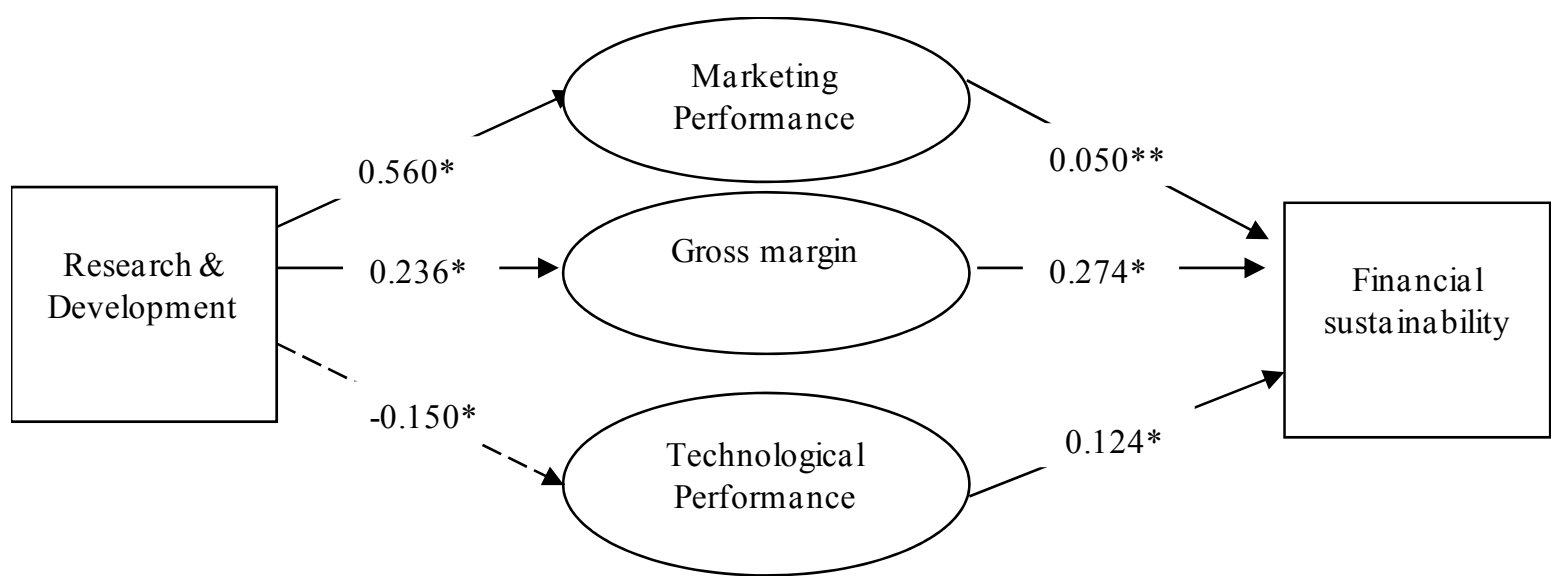

Figure 4. Concluding model

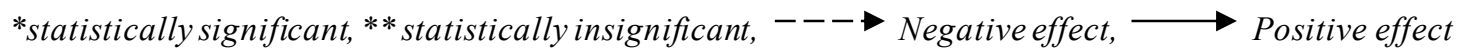

\section{References}

Adams, W. M. (2006). The future of sustainability: Re-thinking environment and development in the twenty-first century. Report of the IUCN Renowned Thinkers Meeting.

Ali, M. A. A. Q. (2011). The operating efficiency and market value of Jordanian privatized firms: Fixed and random effects analysis. Interdisciplinary Journal of Research in Business, 7(1), 99-116.

Altinkemer, K., Yasin Ozcelik, \& Zafer D. O. (2011). Productivity and performance effects of business process reengineering: a firm-level analysis. Journal of Management Information Systems, 27(4), 129-161. http://dx.doi.org/10.2753/MIS0742-1222270405

Ambler, T., \& Kokkinaki, F (1997). Measures of marketing success. Journal of Marketing Management, 13(7), 665-678. http://dx.doi.org/10.1080/0267257X.1997.9964503

Artz, K. W., Norman, P. M., Hatfield, D. E., \& Cardinal, L. B. (2010). A longitudinal study of the impact of R\&D, patents, and product innovation on firm performance. Journal of Product Innovation Management, 27(5), 725-740. http://dx.doi.org/10.1111/j.1540-5885.2010.00747.x

Arvanitis, S., \& Hollenstein, H. (2011). How do different drivers of R\&D investment in foreign locations affect domestic firm performance? An analysis based on Swiss panel micro data. Industrial \& Corporate Change, 20(2), 605-640. http://dx.doi.org/10.1093/icc/dtr006

Basuki, W. A., \& Henderson, S. (2003). Whatever happened to the excellent marketers? A study of financial performance and excellent marketing. Journal of General Management, 9(2), 70-88.

Bronwyn, H. H., Mairesse, J., \& Mohnen, P. (2009). Measuring the returns to R\&D. National Bureau of Economic Research.

Byus, K., Deis, D., Ouyang, B. (2010). Doing well by doing good: Corporate social responsibility and profitability. SAM Advanced Management Journal, 75(1), 44-55. 
Chang, H., \& Su, C.-W. (2010). Is R\&D always beneficial? Review of Pacific Basin Financial Markets \& Policies, 13(1), 157-174. http://dx.doi.org/10.1142/S0219091510001809

Chin, W. W. (1998). The partial least square approach to structural equation modeling. In G. A. Marcoulides (Ed), Modern methods for business research, 295-336. Lawrence Erlbraum Associates.

Corporate R\&D. (2010). Spending rebounds in 2010, finds Booz \& company global innovation 1000 study. Retrieved October 24, 2011, from http://www.booz.com/global/home/press/article/49852237

Cronin, J. J. (1985). Determinants of retail profit performance: a consideration of retail marketing strategies. Journal of the Academy of Marketing Science, 13(4), 40-53.

Danielson, M. G., \& Press, E. (2005). When does R\&D expense distort profitability estimates? Journal of Applied Finance, 15(2), 76-92.

Fang, E., Palmatier R. W., \& Grewal, R. (2011). Effects of customer and innovation asset configuration strategies on firm performance. Journal of Marketing Research (JMR), 48(3), 587-602. http://dx.doi.org/10.1509/jmkr.48.3.587

Feng, C., \& Wang, R. (2001). Considering the financial ratios on the performance evaluation of highway bus industry, Transport Reviews, 21(4), 449-467. http://dx.doi.org/10.1080/01441640010020304

Fornell, C., \& Bookstein, F. L. (1982). Two structural equation models: LISREL and PLS applied to consumer exit-voice. Theory Journal of Marketing Research, 19(4), 440-452. http://dx.doi.org/10.2307/3151718

Franko, L. G. (1989). Global corporate competition: Who's winning, who's losing and R\&D factor as one reason why. Strategic Management Journal, 10(5), 449-474. http://dx.doi.org/10.1002/smj.4250100505

Friedman, M. (1962). Capitalism and freedom. University of Chicago Press.

Ganguli, S. (2009). Impact of R\&D versus marketing on sales growth in Indian industrial sectors. ICFAI Journal of Management Research, 8(2), 55-64.

Gibson, C. H. (1989). Financial statement analysis using financial accounting information.

Gilman, J. J., \& Miller. (1978). R \& D: What link to profits? Management Review, 67(9), 23-26.

Grueber, M., T. \& Studt. (2011). 2012 Global R\&D funding forecast: Industrial R\&D-ICT. Retrieved from http://www.rdmag.com/articles/2011/12/2012-global-r-d-funding-forecast-industrial-r-d-ict

Hall, B. H., Foray, D., \& Mairesse, J. (2009). Pitfalls in estimating the returns to corporate R\&D using accounting data. College of Management of Technology, CEMI - Working Paper.

Hart, S., \& Ahuja, G. (1996). Does it pay to be green? An empirical examination of the relationship between emission reduction and firm performance. Business Strategy and the Environment, 5(1), 30-37. http://dx.doi.org/10.1002/(SICI)1099-0836(199603)5:1<30::AID-BSE38>3.0.CO;2-Q

He, J., \& Huang, Z. (2011). Board informal hierarchy and firm financial performance: Exploring a tacit structure guiding boardroom interactions. Academy of Management Journal, 54(6), 1119-1139. http://dx.doi.org/10.5465/amj.2009.0824

Holak, S. L., Parry, M. E., \& Song, X. M. (1991). The relationship of R\&D/Sales to firm performance: An investigation of marketing contingencies. The Journal of Product Innovation Management, 8(4), 267-282. http://dx.doi.org/10.1016/0737-6782(91)90048-4

Hunton, J. E., Lippincott, B., \& Reck, J. L. (2003). Enterprise resource planning systems: Comparing firm performance of adopters and non-adopters. International Journal of Accounting Information Systems, 4(3), 165-184. http://dx.doi.org/10.1016/S1467-0895(03)00008-3

Income Statement of Hewlett Packard Co. Retrieved from Thomson Reuters Eikon database on 28th February, 2012.

Income statement of International Business Machines Corp. Retrieved from Thomson Reuters Eikon database on 25th February, 2012.

Income statement of Apple Inc. Retrieved from Thomson Reuters Eikon database on 17th February, 2012.

Income statement of Microsoft Corp. Retrieved from Thomson Reuters Eikon database on 25th February, 2012.

Income statement of Dell Inc. Retrieved from Thomson Reuters Eikon database on 25th February, 2012.

Income statement of Intel Corp. Retrieved from Thomson Reuters Eikon database on 25th February, 2012. 
Investment for the future - Benchmarking IT industry competitiveness 2011. (2011). Retrieved from http://globalindex11.bsa.org/upload/key-finding/keyfindings.pdf

Jaruzelski, B., Dehoff, K., \& Bordia, R. (2005). The Booz Allen Hamilton Global Innovation 1000: Money isn't everything. Strategy+business, 41.

Jingjing, Z., \& Rogers, J. D. (2009). The technological innovation performance of Chinese firms: The role of industrial and academic R\&D, FDI and the markets in firm patenting. International Journal of Technology Management, 48(4), 518-543. http://dx.doi.org/10.1504/IJTM.2009.026692

Kenneth, K. (2005). The trade-off between R\&D and marketing spending for high-technology companies. The Journal of American Academy of Business, 7(1), 59-66.

Leonard, W. N. (1971). Research and development in industrial growth. Journal of Political Economy 79(1), 232-256. http://dx.doi.org/10.1086/259741

Lewin, T., \& Chew, E. (2005). High R\&D, greater profits. Automotive News Europe, 10(23), $1 \& 26$.

Lo, C. K. Y., Yeung, A. C. L., \& Cheng, T. C. E. (2011). The impact of environmental management systems on financial performance in fashion and textiles industries. International Journal of Production Economics, 135(2), 561-567. http://dx.doi.org/10.1016/j.jppe.2011.05.010

Mithas, S., Tafti, A., Bardhan, I., Indranil, J., \& Mein, G. (2012). Information technology and firm profitability: Mechanisms and empirical evidence. MIS Quarterly, 36(1), 205-224.

Mittal, V. (2004). Research and the bottom line. Marketing Research, 16(3), 36-40.

Mokhtar, Mohd Z., Karbhari, Y., \& Naser, K. (2005). Company financial performance and ISO 9000 registration: Evidence from Malaysia. Asia Pacific Business Review, 11(3), 349-367. http://dx.doi.org/10.1080/13602380500068441

Morbey, G. K. (1988). R\&D: It's relationship to company performance. Journal of Product Innovation Management, 5(3), 191-200. http://dx.doi.org/10.1016/0737-6782(88)90022-7

Naone, E. (2011). Why Google Wants Motorola. Technology Review (MIT). Retrieved from http://www.technologyreview.com/web/38320/

Onaolapo, A. A., \& Kajola, S. O. (2010). Capital structure and firm performance: Evidence from Nigeria. European Journal of Economics, Finance and Administrative Sciences, 25, 270-82.

Pandit, S., Wasley, C. E., \& Zach, T. (2011). The effect of Research and Development (R\&D) inputs and outputs on the relation between the uncertainty of future operating performance and R\&D expenditures. Journal of Accounting, Auditing \& Finance, 26(1), 121-144. http://dx.doi.org/10.1177/0148558X11400583

Pauwels, K., Silva-Risso, J., Srinivasan, S., \& Hanssens, D. M. (2004). New products, sales promotions, and firm value: The case of the automobile industry. Journal of Marketing, 68(4), 142-156. http://dx.doi.org/10.1509/jmkg.68.4.142.42724

Research and development expenditure (\% of $\quad$ GDP) (n.d). Retrieved from http://data.worldbank.org/indicator/GB.XPD.RSDV.GD.ZS

Robinson, R. T., Munter, P., \& Grant, J. (2003). Financial statement analysis a global perspective.

Rothschild, M. (2006). Shareholders pay for ROA. Strategic Finance, 88(50), 27-31.

Scherer, F. M. (2001). The link between gross profitability and pharmaceutical R\&D spending. Retrieved from http://www.econ.canterbury.ac.nz/personal_pages/john_fountain/Teaching/HealthEcon/reading/HAFMsche rer.pdf

Sher, P. J., \& Yang, P. Y. (2005). The effects of innovative capabilities and R\&D clustering on firm performance: The evidence of Taiwan's semiconductor industry. Technovation, 25(1), 33-43. http://dx.doi.org/10.1016/S0166-4972(03)00068-3

Shin, N., Kraemer, K. L., \& Dedrick, J. (2009). R\&D, value chain location and firm performance in the global electronics industry. Industry \& Innovation, 16(3), 315-330. http://dx.doi.org/10.1080/13662710902923867

Smith, Adam. (1776). An inquiry into the nature and causes of the wealth of nations. University of Chicago Press. ISBN: 0226763749

Sustainability. (n.d.). Retrieved from http://www.artenius.com/sustainability/

Sustainability. (n.d.). Retrieved from http://www.forestry.gov.uk/forestry/edik-59fmzf 
United Nations General Assembly. (1987). Report of the World Commission on environment and development: Our common future.

United Nations General Assembly. (2005). World Summit Outcome, Resolution A/60/1, adopted by the General Assembly

Ural, T., \& Acaravci, S. K. (2006). The effects of firm's strategic factors on export and firm performance: A comparison of permanent and sporadic exporters. Problems and Perspectives in Management, 4(4), 42-62.

Vasilopoulos, A. (2011). Hypothesis testing: A statistical procedure for testing the validity of claims. Review of Business, 32(1), 89-110.

Verbeeten, F. H. M., \& Pieter, V. (2010). Are brand-equity measures associated with business-unit financial performance? Empirical evidence from the Netherlands. Journal of Accounting, Auditing \& Finance, 25(4), 645-671.

Luckham, W. R. (1982). Six ways to increase owner's returns on investment. Journal of Arboriculture, 8(11), 302-304.

Waddock, S., \& Graves, S. B. (1997). The corporate social performance: Financial performance link. Strategic Management Journal, $303-319$. http://dx.doi.org/10.1002/(SICI)1097-0266(199704)18:4<303::AID-SMJ869>3.0.CO;2-G

Wang, H., \& Qian, C. (2011). Corporate philanthropy and corporate financial performance: The roles of stakeholder response and political access. Academy of Management Journal, 54(6), 1159-1181. http://dx.doi.org/10.5465/amj.2009.0548

Wheelen, T. L., \& Hunger, D. J. (2002). Strategic Management and Business Policy. (8th ed.). New Jersey: Prentice Hall.

2012 Global R\&D funding forecast. (2011, December). Retrieved from http://battelle.org/docs/default-document-library/2012_global_forecast.pdf

\section{Notes}

Note 1. R\&D: Research and development

Note 2. ROA: Return on assets

Note 3.R\&D expenditure: Research and development expenditure

\section{Copyrights}

Copyright for this article is retained by the author(s), with first publication rights granted to the journal.

This is an open-access article distributed under the terms and conditions of the Creative Commons Attribution license (http://creativecommons.org/licenses/by/3.0/). 